\title{
Euro indecision triggers food anarchy
}

Yet again, products from biotechnology have been caught in the crossfire of European compromise. On November 1, the European Union's Novel Food Regulations requiring that foods containing genetically modified soy or corn be labeled came into force. On the same date, however, the Standing Committee on Foodstuffs-a committee of officials drawn from European Union member states-failed to agree whether the trigger for the labeling rule should be protein- or DNA-based tests. The European Commission (Brussels) has also failed to agree on a form of words that would be appropriate on a food label.

All this has left European food companies with "more confusion than before [the Novel Food Regulation]," according to Willy de Greef, of the consultants Applied Life Science Strategies (Zwijnaarde, Belgium). He dates the confusion to the emergence of the novel food rules back in May this year. "Everyone was rushing through the regulations on the assumption that it would solve the uncertainties," he says, "but the European Commission shied away from all the important details like defining a genetically engineered food or designating a threshold level of modified ingredients." The regulations that were agreed in May stated that "detailed rules will be published as soon as possible." To date, the provision of guidance that is of practical use to food companies has not proved possible.

The Standing Committee's indecision has also set back some of the national efforts to interpret the Novel Foods Regulations. In response to requests from a soy-processing company called Protein Technologies International, a Ypres, Belgium subsidiary of Ralston Purina (St. Louis, MO), the government in the Netherlands proposed that the detection of proteins from modified organisms should be the trigger for labeling. However, a Dutch court recently ruled that the move was illegal, partly because the existing Dutch laws were not designed to cover recombinant processes, and partly because the court expected detailed guidance to come through European fora.

The food companies and the national food regulation bodies within Europe are now operating within a legislative vacuum. Within very broad limits, they are free to apply their own interpretation of the Novel Food Regulations. The Swiss multinational Nestlé (Vevey) plans an empirical approach to feel out the new legislation, according to Claus Conzelmann, a vice-director responsible for regulatory affairs. For soy, for instance, it will undertake PCR-based tests in its own laboratories and, if the Roundup Ready gene (the gene encoding 5-enol pyruvylshikimate-3phosphate synthase) is detected, it will label the foodstuff-but only if the food contains soy protein. Foods containing soy oil or soyderived lecithin only will not be labeled. The reasoning, says Conzelmann, is that the food product itself is only altered if it contains soy proteins. The wording used on the labelsNestle's own phrasing - will be "Modified by modern biotechnology."

It will then be up to the various national regulatory authorities to judge whether Nestle's interpretation of the Novel Food Regulations is acceptable, says Conzelmann: "If they agree, fine. If they don't agree, then it is also fine, because we will find out what their interpretation is and react accordingly." Nestlé has already virtually run down its stocks of nongenetically engineered soy and its first "modified-labeled" products will be on the market soon. They are likely to be soy-based infant formulas sold in Belgium and Italy, and specialty nutrition products for hospital use.

There is still a chance that a return to national regulatory anarchy could be avoided, but only if the European Commission comes up with an acceptable formula by the next meeting of the Standing Committee on Foodstuffs, on December 16 or 17. As the committee has already rejected both protein and DNA tests, the room for maneuver is considerably limited. If it rejects the new proposals as well, the commission will present proposals directly to the council of national industry ministers, which will then have three months to approve them (by majority) or reject them (unanimously). In private, officials within DGIII, the department of the European Commission that drew up the Novel Foods Regulations, are exasperated at the member states' failure to agree on any detailed guidance.

John Hodgson

At the end of October, the New Zealand parliament rejected a bill that would have required food manufacturers to label genetically modified foods. International trade considerations played an important role in the governments decision to vote down the bill, according to Associate Health Minister Tuariki Delamere. J.H.

\section{Firms sleuth out transgenic foods}

From November 1, products containing genetically modified soybean or corn must be labeled as such in European Union countries (see above, "Euro indecision triggers food anarchy"). Thousands of tests of food and food ingredients are now taking place across Europe, and a coterie of companies-including at least one with a clear political agendais seizing this business opportunity.

When transgenic soybeans and corn were introduced two years ago, many Europeans had been primed for distrust of new food by the panic over "mad cow disease" (bovine spongiform encephalopathy). Consumers and their commercial proxy, the retailers, wanted segregation of transgenic from nontransgenic crops, but that was opposed on the grounds of impracticality and expense by agricultural interests in the United States, and the stage was set for the European

Douglas Steinberg is a freelance writer working in New York. Additional reporting by John Hodgson.
Commission's labeling requirement.

Companies testing food for genetic modifications include Genetic ID (Fairfield, IA), Biodelta (Bad Oeynhausen, Germany), Gene-Scan (part of Hydrotox, Freiburg, Germany), Genolife (Saint Beauzire, France), Hanse Analytik (Bremen, Germany) and TNO Nutrition and Food Research Institute (Zeist, the Netherlands). Between them, the companies will have conducted around 10,000 tests for genetically engineered food by the end of 1997. Andreas Wurz, manager of analytical affairs at Gene-Scan, for instance, says that his company alone undertook 2,000-3,000 tests in the past 12 months.

One of the evangelists in transgenic food detection is Genetic ID, a privately owned eight-person company in Fairfield, Iowa formed in mid 1996. "When the demand for testing emerged in Europe, then it's natural for businesses to crop up to meet that demand," recalls John Fagan, the firm's laboratory director. Genetic ID was somewhat ahead of the game in developing a series of PCR-based tests for genetically engineered 